\title{
The evaluation of the supply chain management challenges South African fashion designers experience in the retail clothing environment
}

\author{
Boitumelo Pooe \\ Virimai Mugobo \\ Department of Retail Business Management \\ Cape Peninsula University of Technology, Cape Town, South Africa
}

\section{Keywords}

South African Fashion Designers, Retail, Clothing, Challenges, Supply-Chain-Management Model

\begin{abstract}
The purpose of this paper was to investigate the challenges South African fashion designers experienced when managing their supply chain network in the retail clothing industry. In today's complex markets, the susceptibility of the supply chain is viewed as an ongoing issue for several industries and it is no different for fashion designers. As a result, in the past, the visibility of South African fashion designers in the retail environment appeared to be minimal, due to a number of challenges.

This paper is based on qualitative research that made use of in-depth semi-structured interviews with a total of twenty-four participants, with the sample divided into five groups representing different industry professionals. Semi-structured interviews allowed the participants to answer the questions unreservedly based on their own personal and professional experiences. The findings revealed that South African fashion designers in the retail industry experienced a number of supply chain challenges such as cash flow and funding, fabric, challenges associated with cutting, making and trimming (CMT) companies, skills and knowledge, fashion designer's business acumen, market access and location, human skilled resources, garment and production quality, fragmentation, costing, marketing, competition, and other isolated challenges that were mentioned by a few participants.

The practical implications of this paper include the need for responsible stakeholders to put in place mechanisms to reduce the supply-chain-management challenges South African fashion designers are facing in the retail clothing industry. As a result, close proximity supply chain networks that could support effective communication amongst members of the supply chain are recommended.
\end{abstract}

Corresponding author: Virimai Mugobo

Email addresses for the corresponding author: mugobov@cput.ac.za

First submission received: $23^{\text {rd }}$ June 2020

Revised submission received: $30^{\text {th }}$ August 2020

Accepted: $9^{\text {th }}$ September 2020

\section{Introduction}

There is an extensive supply chain (SC) process between designing and retail sales, which has proven to be a challenge for the South African's (SA) clothing industry (Ramdass, 2011:1), including fashion designers. The challenges the SA clothing industry faces on the retail front have not been explicitly researched or documented, and as a result the exact problems SA fashion designers in the retail environment encounter within the SC are still largely unknown. Therefore, it is critical to investigate the challenges that SA fashion designers experience when managing the clothing SC in the retail industry, in order to establish suitable solutions that could potentially safeguard the operational functions of SA fashion designers in the retail industry.

The demands exerted by fashion trends on the clothing SC were observed as unpredictable, as fashion retailing required a responsive, flexible and accurate SC model to succeed in the continuously changing seasons and channels of distribution (Jackson, 2009:22). It is the view of the researchers, that until SC challenges are identified, the industry may not be able to develop an accurate, responsive, and flexible SC model for SA fashion designers in the retail clothing environment. During past years, the SA retail clothing industry witnessed fashion-design brands such as Sun Goddess shutting down four of their retail outlets (Nyhaba, 2009). The fashion label Stoned Cherrie also closed its flagship store, in Rosebank 
(Ngubane, 2011), and this was followed by the termination of a two-year partnership with major retailer Foschini (Madikwa, 2011). In addition, Stoned Cherrie experienced a short-lived partnership with another major retailer, Woolworths, when its "diffusion line" (ready-to-wear) was discontinued (Woolworths, 2009).

While the abovementioned fashion designers experienced retail-outlet closures, other fashion designers were acquired by major retailers. One of these was Jenni Button, whose business was purchased by then major holding company Platinum Group (Pitman, 2009), which unfortunately underwent liquidation during 2015 (Moorad, 2015). Platinum Group was also the holding company of other South African designer brands such as Vertigo, Hilton Weiner, and Urban Degree. Another fashion-designer brand, Marion \& Lindie, was first acquired by the holding company Busby before announcing its national retail outlets' closures over social media in 2013. Lastly, Young Designers Emporium (YDE), which retails emerging and established South African fashion designers, was acquired by listed retailer Truworths (Anon, 2004), affecting fashion designers' SC management and product control. Truworths had also previously acquired South African fashion brands such as Naartjie and Earthchild (Truworths, 2015). The challenges experienced by fashion designers which led to the abovementioned closures, take-overs and acquisitions are not publicly available, and this evoked the researchers' interest in this study.

\section{Problem Statement and Motivation for the Research}

It is evident from Pitman (2009), Moorad (2015) and Truworths (2015) that there are several challenges being experienced by SA fashion designers in the retail clothing industry. As SA fashion designers move from specialising in tailored or bespoke garments to producing larger quantities in retail, there are bound to be SC model adjustments, because of the changes in consumer demand, the increase in competition and the greater labour forces required. However, the problem is that the challenges experienced within the SC process have not been extensively researched and documented.

Thus, the purpose of this study was to identify the challenges SA fashion designers encounter at each level of the SC when producing for the retail clothing industry. The study also sought to establish the strategies that could be used to ameliorate these challenges.

\section{Literature Review}

Shukla (2016:44) describes the SC as a range of organisations performing specialised activities to execute an end goal. Consequently, the performance of the specialised activities within the SC of SA fashion designers was evaluated to determine the potential challenges that could affect the end goal in the retail clothing environment. Accordingly, this literature review, firstly, looked at the relationship of the SC activities and secondly, assessed the different SC dynamics that contributed to the sourcing of raw materials and manufacturing processes in SA.

\section{Supply-Chain-Management Model Relationships}

Christopher (2000:1) explained that SCM included the upstream and downstream relationship between an organisation and its suppliers, distributors and clients to accomplish better value for the SC. Christopher and Towill (2002:3) demonstrated that the flow of orders was upstream, while the flow of materials was downstream. Masteika and Čepinskis (2015:832) illustrated that materials flowed forward, starting with the planning process by suppliers, then forecasting, followed by procurement, trailed by manufacturing, proceeded by distribution and logistics, and finally carried through to customers.

However, the limited exchange of information between adjacent entities within the SCM system created unforeseeable challenges that could be avoided through the flow of information (Christopher \& Peck, 2004:12), and in the fashion industry, trend forecasting platforms are known to support the flow of information. Fashion-forecasting packages were generally published one or two years in advance and cost above $€ 1000$ (over R15 000.00), as the process required the correlation of books and online resources compiled by entities who have either gone through extensive travel to seek out preliminary signs of change or have attended think-tank seminars with experts on social, cultural and creative movements (Giertz-Mårtenson, 2010:138). It could therefore be argued that the cost of fashion-forecasting limited the exchange of information, but, Gaimster (2012:169) proved that the nature of fashion forecasting had changed dramatically due to technological innovations speeding up the flow of free information, resulting in the creation of a more diverse marketplace. 
These uncertainties, complications, and challenges of SCM models required new integrations within the SCM ecosystem, including the forward flow of information and backward flow of cash (Masteika \& Čepinskis, 2015:832). A manufacturer that engaged and was involved in retail activities would be considered as "forward integrated", whereas a retailer engaged in production would be referred to as "backward integrated". This forward and backward integration is also referred to as "vertical integration" (Ayers \& Odegaard, 2017:7). In relation to the quick-response (QR) model, Christopher and Towill (2002:2-3) elucidated that the SC consisted of bi-directional flows, the forward flow from the producer to the customer, followed by the backward flow of information about customer demand and orders, and over and above that, a backward flow of information that assists retailers to acquire the required margins, regardless of retail formats (Ayers \& Odegaard, 2017:7). While Seuring and Müller (2008:170) explained that the core essence of a sustainable SC model was the management of materials, information, and capital flows, together with the collaboration between organisations along the SC.

It is important to note that backward integration is crucial, as Peck (2005:211) advised that the principle of having a strategy that kept some options open should be applied when developing a resilient SCM model. Christopher and Peck $(2004: 13,17)$ further stated that the way forward in creating a resilient SC was through high-level collaboration between entities within the SC, but creating the conditions in which collaborative working becomes possible could potentially pose some challenges. Recognising this need, Ayers and Odegaard (2017:12-13), in agreement with Christopher and Peck, pointed out that one of the challenges was the limitation of required skills to implement the undertakings. However, those limitations could be avoided through the implementation of collaborative relationships, first within the organisational structures to support the external collaborative relationships, second through forging up and down SC partnerships with trading partners to gain competitive advantage, and third through managing SC information and employing technological innovations.

Christopher and Peck (2004:1) further reiterated that improved management and control of internal processes and information flow within and between the SC entities would assist with the attainment of the ideals of a fully integrated, efficient and effective SCM model capable of mitigating challenges. Notably, most retailers work with layers of bureaucracy, creating a communication barrier between departments, but, for example, Zara's operational structures and performance measurements, together with its office layouts, are all designed for simple information transfer (Ferdows et al., 2005:1). Zara is known for its fast fashion and over time, the apparel industry evaluated the impact of clothing on sustainability, and as a result, slow fashion emerged as a sustainable solution (Jung \& Jin, 2016:510). Opposingly, Fletcher (2010:259), argued that fast fashion was not necessarily unsustainable but a strategy that delivered economic growth and increased sales. However, expedited manufacturing in fast fashion resulted in low quality, poor working conditions, low prices, and apparel with a short life cycle due to the fast-changing trends (Jung \& Jin, 2016:14).

In support, Fernie and Sparks $(2009: 5,11)$ wrote that the key factors in management were to ensure that product availability was easy, maximising the efficiency of the SC and ensuring that retailers closely collaborated with suppliers to ensure effective coordination of activities. Sirilertsuwan et al. (2018:1346) revealed that close-proximity clothing manufacturing advances sustainability while benefiting the bottom line. Their findings further showed that governments' role in supporting the improvement of proximity manufacturing involved the formation of clothing-industry clusters with different types of suppliers and service providers; the issuing of favourable trade policies; the utilisation of carbon-footprint taxation on imported garments; the offering of tax credit for proximity garments; recycling-programmes support; machinery, technology and business-operations financing support; education support; processdevelopment support; business-collaboration support; technical business-infrastructure support; the sharing of resources with neighbouring governments; the implementation of environmental laws and regulations for water usage, chemical release, gas emission and filtration technology; the offering of clean sources of energy; beneficial labour laws and regulations; stringent health regulations and laws; and, finally, the passing of acts to ensure that the country of origin can be identified in advertising. However, in SA there are numerous dynamics that have affected all the above-mentioned factors. 
Dynamics of Sourcing for Raw Materials and the Manufacturing Functions for South African Fashion Designers Supplying Retail

Ready to Wear (RTW) designers are located in numerous locations around the world. Hence the coordination and logistic processes of production are emphasised, as the production of RTW garments is labour intensive, but the initiation of production requires less capital and technology than other businesses. This is why the business of RTW clothing has been deemed to be of high importance to the economies of developing nations in the twentieth and early twenty-first centuries, and to entrepreneurs of these eras. (Druesedow, 2010:591)

SA fashion designers have been operating within the retail environment with RTW ranges for over fifteen years. According to Palmi (2007:29), over twelve years ago there were already media reports indicating that retailers were providing opportunities and retail space to established and recognised local designers. This meant, however, that there were limited retail opportunities for start-up fashion designers, and as a result, fashion designers who were just starting their businesses would encounter challenges in gaining market penetration and market share within the retail environment.

While some fashion businesses used to produce everything in-house, they have increased their outsourcing to manufacturers to gain competitive advantage and lower manufacturing costs, while reducing internal capital expenditure on training, supervision, workforce and non-core equipment and systems (Burke, 2013:47). Nonetheless, disadvantages to be taken into consideration when outsourcing include challenges around quality management, restrictions on capacity, probabilities of failing to meet due dates, disruption risks, discounting schemes, and the reliability and flexibility of the selected suppliers (Kaya, 2011:168). One other major disadvantage of outsourcing was the communication barriers between the fashion designer and the manufacturer, though outsourcing locally enables the fashion designer to employ the manufacturers when needed (Burke, 2013:47). However, according to Jackson and Shaw (2001:137), manufacturers are compelled to be more competitive than ever, with pricing, design, quality, delivery, and value for money as the current market exhorts pressure.

SA's clothing-manufacturing industry is certainly not without its own risks and challenges (Fin24, 2018). The historically well-established manufacturing industry in SA previously supplied a variety of products, from basic and low-cost products to high-fashion and bespoke products (Kesper, 1999:143). As a result, the SA fashion clothing industry consists of a few large factories, which are referred to as fullpackage manufacturers (FPMs), but it is important to note that most apparel producers or manufacturers for fashion designers are spread across medium-sized, micro-factories and survivalist operations referred to as "cut, make and trims" (CMTs) (Tilly et al., 2013:3). Conversely, for small-businesses, proximity manufacturing and other small manufacturers specialising in a smaller niche markets were essential for the survival of those businesses (Burke, 2013:47).

Since the closures of a number of manufacturing mills in the late 1990s, it became increasingly difficult to locate reliable manufacturing facilities in SA willing to produce the minimum units SA fashion designers often required (Entrepreneur Magazine, 2018:6). Furthermore, SA's clothing-manufacturing industry's challenges and risk profile were exacerbated by the $22 \%$ tax imposed on raw materials imports which are essential input for the clothing manufacturing industry. In addition, foreign investment had often bypassed the clothing-manufacturing industry in SA, to invest in neighbouring countries such as Lesotho, Swaziland, Madagascar, and Mauritius (Fin24, 2018).

A significant portion of fabrics and yarns used in SA are now imported, as domestic fabrics and yarns are perceived as more expensive than the imported equivalents even after duties have been applied (Roberts \& Thoburn, 2004:128). The Textile Federation (2007) acknowledged that the textile industry in SA had encountered challenging trading conditions, with decreasing employment due to the shutdown of textile mills since the early 2000s, forcing the retrenchment of staff, as there was an influx of imports, with a 29\% increase in imports between the years 2001 and 2006, from 77000 to 99000 tons, and an additional $500 \%$ increase for synthetic fabrics.

Globalisation has exemplified its opportunities and threats through the textile industry, as the subSaharan-African textile industry contributes to a significant percentage of employment in the manufacturing sector, so necessary adjustments in the local industry would have a significant effect on income and employment locally (Roberts \& Thoburn, 2004:126). Business Partners (2014) optimistically 
noted that, though the SA textile and clothing industries are small, their aim was to utilise all the natural, human, and technological resources available nationally to ensure that these resources become soughtafter internationally. In addition, the Department of Trade and Industry (DTI) reported that there are plans under way to unveil new strategies to protect the local textile industry (Hans, 2019).

\section{Research Methodology}

The philosophical approach of this paper was interpretivism, as it was imperative to understand the role of individuals, who are SA fashion designers, in their respective circumstances, thus interpretivism emphasises the necessity of conducting research among individuals in their particular roles (Saunders et al., 2015:129). Additionally, subjectivism was the researcher's stance to understand the reality of the situations, and to appropriately study the details of the existent situations. As a result, this research study was based on studying the details of the SC challenges SA fashion designers experience when producing for the retail clothing industry in order to understand their subjective realities in depth and to document them accordingly. Moreover, this study's focal point was on the investigation of individuals' experiences as challenging situations materialise, which is referred to as pragmatism (Shields, 1998:197).

The research approach of this study was qualitative, as the "interpretive, naturalistic approach to the world" (Denzin \& Lincoln, 2000:3 cited by Snape \& Spencer, 2003:3) or SC challenges of SA fashion designers in the retail clothing industry was required. Furthermore, the qualitative approach presents a comprehensive understanding of the participants' environment (Snape \& Spencer, 2003:4), which was required in order to fulfil the objectives of the study. The qualitative method was appropriate to this research as it allowed content generation because most SC model challenges SA fashion designers experience in the retail environment were still unknown (Gaille, 2018).

A research strategy is the action plan (data-collection process) that provides direction in order to conduct research systematically, to produce accurate results and detailed reporting (Dinnen, 2014:1). Firstly, as this was a qualitative research, the inductive method was applied, which grounded the theory in data, allowing the theory and the data to relate (Neuman, 2011:177). Ground theory was used to take the data apart then sort, synthesise, and summarise that data to define how that data was linked Charmaz (2011:363).

The data was collected by means of in-depth, semi-structured interviews. The in-depth interviews which are closely associated with qualitative research, allowed the researcher to conduct interviews that were naturalistic, though the conversation would have had minimal resemblance to an everyday conversation (Legard et al., 2003:138). The interviews were also semi-structured to allow the scope of conversation to flow effortlessly during the process, as this was deemed as ideal as participants could answer the questions unreservedly based on their own personal and professional experience (Jensen \& Laurie, 2016:173). The interviews were "status" or "one-shot" studies, referred to as cross-sectional, to determine the overall view of the situation at the point in time, and which was paramount in determining the prevalence of the specified situation (Kumar, 2014:368).

\section{Data Collection Process}

A total of twenty-four individual interviews were conducted, with the sample divided into five groups: seven South African fashion designers; seven fashion retailers and agents or consultants; four fashion education institutes, four government institutions, and two fashion councils. The details of the population groups are outlined in Table 1 below.

Participants from the different population groups represented various regions in South Africa; therefore, the researcher travelled to the various provinces to conduct the interviews.

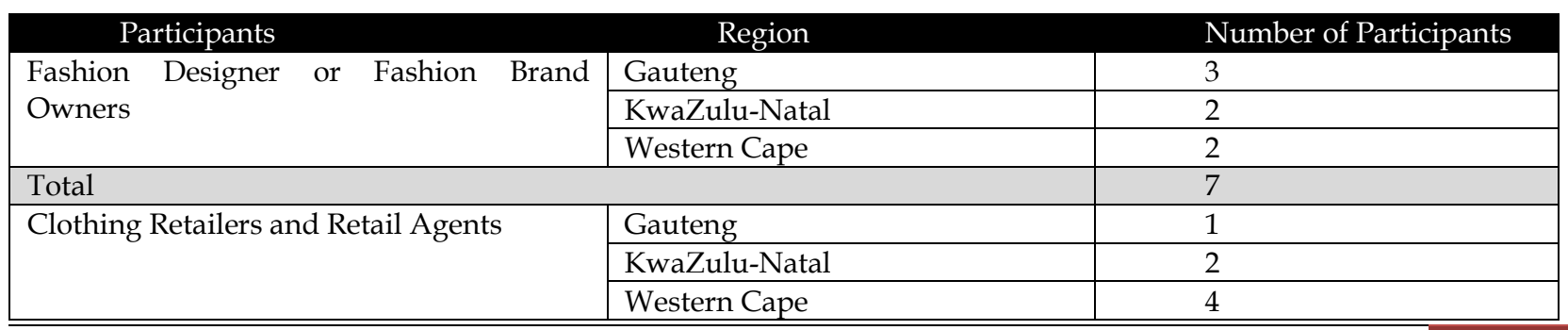

www.jbrmr.com A Journal of the Centre for Business \& Economic Research (CBER) 


\begin{tabular}{|c|c|c|}
\hline \multicolumn{2}{|l|}{ Total } & 7 \\
\hline \multirow{2}{*}{$\begin{array}{lrr}\text { Fashion } & \text { Educational } & \text { Institution } \\
\text { Representatives } & \text { and Skills } & \text { Development } \\
\text { Agents } & & \end{array}$} & KwaZulu-Natal & 3 \\
\hline & Western Cape & 1 \\
\hline \multicolumn{2}{|l|}{ Total } & 4 \\
\hline \multirow{2}{*}{ Government Institutions } & National (Based in Gauteng) & 1 \\
\hline & KwaZulu-Natal on & 3 \\
\hline \multicolumn{2}{|l|}{ Total } & 4 \\
\hline \multirow[t]{2}{*}{ Fashion Council } & KZN Fashion Council & 1 \\
\hline & Cape Town Fashion Council & 1 \\
\hline \multicolumn{2}{|l|}{ Total } & 2 \\
\hline
\end{tabular}

Table 1: Population Groups

\section{Data Analysis Process}

Through the data-analysis process, the empirical data was analysed by utilising a coding process intended to simplify the complexity of the data collected and to reach a conclusion based on reasoning (Neuman, 2011:478).

The data collected was analysed through the use of a qualitative data-analysis (QDA) software, otherwise referred to as computer-assisted qualitative data-analysis software (CAQDAS) called Atlas.ti (Hwang, 2008:519). During the analysis of data, Atlas.ti version 8 offered systematic tools for the transcribed data that could not be analysed through the use of statistical approaches (Atlas.ti, 2018:9).

The coding process allowed large segments of transcribed data to be simplified so that a link and a common thread could be identified and assessed (Belotto, 2018:2525). Practically, coding is the process of allocating categories or concepts to segmented transcriptions that are linked to the research objectives, while code groups are clusters of codes utilised as filters (ATLAS.ti, 2018:11,16). Additionally, sub-codes were allocated to threads or themes that recurred within the codes. Finally, from the five population groups, a total of five code groups, twenty codes and twenty-six sub-codes emerged.

\section{Findings and Results}

The interviews with SA fashion designers and stakeholders confirmed that there were several challenges being experienced by fashion designers. As the interviews progressed, some challenges were mentioned more frequently. As a result, the following sub-headings of challenges emerged: cash flow and funds were mentioned twenty-eight times, fabric was mentioned twenty-six times, CMTs were mentioned twenty-three times, skills and knowledge were mentioned eighteen times, the business acumen of fashion designers was mentioned seventeen times, market access and location were mentioned thirteen times, human skilled resources was mentioned twelve times, quality was mentioned eleven times, fragmentation was mentioned eleven times, costing was mentioned nine times, marketing was mentioned eight times, competition was mentioned five times, and other isolated challenges were mentioned ten times.

\section{Isolated Challenges}

The isolated challenges that were mentioned were: technological challenges; low barriers of entry to the fashion industry, which affected the credibility of SA fashion designers; confusion from consumers due to the re-branding required from high-end fashion designers who enter the retail industry; challenges with trade rules, legislations and policies; false or misleading claims regarding local production by government departments and retailers; and lack of foreign investment in the country's value chain from foreign businesses operating in SA.

\section{Cash-Flow and Funding Challenges}

The main challenges identified with cash flow and funding were the following: the purchasing power of the SA market, which appeared to not generate enough revenue for SA fashion designers; the availability of and accessibility to loans and funding for SA fashion designers from banks and government institutions; the government's focus on and allocation of funding to bigger businesses, which results in the marginalisation of smaller businesses such as local fashion designers; limited information on funding 
opportunities from government institutions; limited budgets from funding and government institutions; the thirty- to sixty-day payment method most retailers enforce when they procure product from SA fashion designers; the concession and consignment model, which works on a commission basis; the historically disadvantaged background of some SA fashion designers, which made it more difficult to attain funding and financial support; the short-term funding relationships between government institutions and clusters meant to support the industries; the raw-material and production costs used for replenishment and increased orders from retailers; fast business growth experienced by certain fashion designers due to demand - as a result of this growth it was found that increased SC capacity was necessary, which required additional cash flow; the inability of fashion designers to manage finances by scaling up their business while saving for business needs; and the production costs incurred when fashion designers worked with large volumes.

\section{Challenges with Fabric}

SA fashion designers, retailers and stakeholders confirmed that fabric was one of the biggest challenges faced, due to the following factors: the cost of quality fabric when producing for the retail industry; the turnaround time when printing fabric for the retail industry; the limited fabric-production mills and manufacturers in South Africa, which resulted in limited fabric locally; the limited fabric knowledge fashion designers demonstrated when producing for the retail industry, which resulted in compromised quality and standards; the increasing number of imported fabric, with some local fabric mills being forced to shut down; and the leniency of import duties and policies surrounding the importation and distribution of textiles.

\section{CMT Challenges}

The findings confirmed that most CMTs preferred to work on larger orders and were not willing to work with the minimum quantities SA fashion designers requested, but when some of the CMTs agreed to work with the fashion designers, they would charge them higher prices for production, while the fashion designers and retailers found that the CMTs produced quality that was below the retail standards. On the other hand, several CMTs in SA were closing down due to a lack of skill and increasing competition from international manufacturing companies. The different dynamics within each province also created challenges for fashion designers, as that made the management of the supply-chain process difficult for fashion designers who desired to work with CMTs in close proximity.

\section{Challenges with Skills and Knowledge}

The participants expressed continuous concern regarding the lack of skills and knowledge SA fashion designers demonstrated with regards to the management of the supply-chain process in the retail environment. It was found that some factors contributed to this lack of skills and knowledge, and those factors were: the limited SC management exposure provided by fashion education; the competitive approach of the educational institutions when it came to fashion education; jargon and SC expectations when entering into procurement contracts; the generalisation of fashion and garment skills from fashion education, which resulted in a lack of specialised skills; the deterioration of the textile industry since 2002, which has resulted in lost skills from experts within the industry; the limited business training and emphasis from fashion education, fashion designers and the industry as a whole; the lack of research and information centres in SA for fashion designers; the lack of infrastructure in terms of skills enhancement; masked internship programmes, which offer limited knowledge, skills and education to individuals; the lack of value placed on certain areas of the SC process by stakeholders as a whole, creating a deficit of skills in a number of areas within the SC model.

\section{Challenge in Business Acumen}

One of the challenges that came out was the fashion designers' lack of business acumen in terms of the following factors: understanding of the SC structure and capacity when approached by distributors or retailers; benchmarking abilities; understanding of retail business processes; focused business planning that caters to a specific market; drive, which leads to complacent attitudes towards supporting institutions; business administrative skills; business processes; respect for deadlines; and overall 
consistency. It was also found that there was a limited understanding of the sales matrix, sales graphs, and retail planning mechanisms.

\section{Market Access and Location Challenges}

The participants confirmed that there were challenges with SA fashion designers' location, market access and the market in general, which were closely linked to: cash flow and funding; marketing challenges; SA consumers' shopping habits; availability and access to retailers SA fashion designers could potentially supply; incorrect selection of location or the lack of availability of prime locations; the limited understanding of the SA market by SA fashion designers, due to the limited data available; and lack of professions to hire the specialised skills required for the management of the clothing SC in SA.

\section{Challenge of Skilled Human Resources}

It was revealed that another of the challenges closely related to skills and knowledge was with the availability of human skilled professionals to assist SA fashion designers supplying the retail clothing industry.

\section{Quality Challenges}

Some respondents noted that quality was one of the challenges South African fashion designers encountered with the management of the supply-chain process when supplying the retail industry. Moreover, it was found that quality affected the patronage of South African fashion designers' products by retailers and consumers alike, as mediocracy was embraced rather than being addressed.

\section{Fragmentation Challenges}

The findings illustrated that fragmentation was one of the factors that contributed to the difficulties SA fashion designers confronted when managing the clothing SC for the retail environment. Fragmentation challenges involved, inter alia, the following factors: work done in isolation, which resulted in intensified levels of competition and lack of collaboration between local fashion designers; lack of communication and follow-through between government departments supporting local fashion designers; unequal and lack of availability of supply-chain structures in one province or one area; limited support, offerings and resources for the management of the SC process at fashion weeks for fashion designers in the retail environment; and lack of shared information between institutions.

\section{Costing}

Costing challenges were mentioned by some participants, who highlighted that there were product offerings by SA fashion designers with price points that appeared too high compared to the value proposition and quality of the garments. Furthermore, the price points of local fashion designers were found to be too high for local retailers and local consumers, due to the smaller margins of production. The level of preparedness when costing a garment also appeared questionable, as there were local fashion designers who would cost a garment before considering all the materials and factors required. And other local fashion designers would not set the appropriate mark-up to justify or educate the consumer about their particular price points.

\section{Marketing Challenges}

The study also established that marketing was one of the challenges SA fashion designers faced when managing their SC process for the retail industry. The marketing challenges were linked to market access and information, and finally with cash flow and funding connected with the cost of showcasing at fashion weeks. The government initiatives that supported the showcasing of SA fashion designers at different national and international platforms were found to be planned in isolation, with no consistency and without the consideration and input of the local fashion designers. On the other hand, retailers were found to provide minimal to no marketing support to SA fashion designers who supplied their stores.

\section{Competition}

One of the challenges that was not a major concern for most of the participants was competition. Competition was closely related to the high price points of local fashion designers, as larger retailers offered lower price points for similar products and the second-hand market offered designer clothing at lower prices. Plus, some participants highlighted that SA consumers are exposed to many international 
high-end brands that have been in existence for a longer period, which means that they may have an established market share.

\section{Retailers' Challenges with South African Fashion Designers}

Communication barriers were one of the challenges which were found from both the retailers' and the local fashion designers' points of view. Other challenges included the level of commitment from local retailers to work with South African fashion designers, overseas production by local retailers, the absence of a national fashion council in South Africa, and local retailers' expectations of South African fashion designers.

Local retailers' commitment to work with South African fashion designers was then questioned, as the retailers appeared to use South African fashion designers as marketing tools to appease a certain mind-set, rather than working with them as business associates. The concession or consignment model came under scrutiny by some participants, as they stated that the model had not supported the local fashion designers' cash flow and finances, while it demonstrated a non-collaborative relationship between South African fashion designers and local retailers.

Some of the participants also stated that the quantities expected by large retailers were too high to produce for SMMEs such as South African fashion designers. It was found that the price of differentiation appeared to be too high for retailers in the current slow economy.

While retailers were manufacturing most of their products in China, they found that procuring products from overseas affected their desired fast-fashion models. At the same time, it was noted that investors (such as retailers) required to see profits continuously, and this was perceived by other participants as unsustainable for South African fashion designers. Moreover, the shift to overseas production by retailers created unemployment within the clothing supply chain, which then created a negative ripple effect, resulting in the loss of skilled workers, then the loss of taxes, and finally a negative effect on the economy.

South African Fashion Designers Weaknesses in Managing the Supply-Chain Model for the Retail Clothing Industry

The weaknesses mentioned by participants included: quality standards, quality measures and technical understanding, which required attention to design detail; the degree of knocked-off designs within the fashion and retail industries; unsuitable pricing strategies for high-end brands and an inability of certain fashion designers to plan and strategise towards a functional fashion business dream or vision; inconsistent creative input from several fashion designers; ego-driven attitudes among some fashion designers; limited offering of basic or staple designs by South African fashion designers; poor customer service, ownership and management by a number of fashion brands; lack of specialisation or focus towards brand offerings; and the under-valued uniqueness of African and South African design by local fashion designers and retailers.

\section{Discussion on Findings}

Literature and empirical studies discussed in section 2 have also identified a number of these challenges in the past. One of the most frequently mentioned challenge by participants was with regards to cash flow and funding. Druesedow (2010:591) pointed out that the production of RTW garments was labour intensive, but the initial production required less capital and technology than other businesses. The findings of this research study contradict Druesedow's assessment, as participants acknowledged that more capital was required when producing RTW products for the retail industry and the management of the SC process.

Some participants recognised that one of the major challenges within the SCM process was the development of technology within the design and manufacturing sector in SA. In support of this argument, Tobler-Rohr (2011:46) also affirmed that technology and quality are acceptable parameters to support the flow of material within the textile SC, as functions such as spinning, weaving/ knitting and finishing typically take place at a single facility, with the finishing process undertaken by a subcontractor.

Closely linked to technology were the manufacturing challenges, which were mentioned more frequently by participants. Both product manufacturing and textile manufacturing were the two frequently mentioned challenges, after cash-flow and funding challenges. In line with these findings, 
Fin24 (2018) argues that the SA clothing-manufacturing industry was not without its risks and challenges. One of the major challenges found with manufacturing was the unwillingness of manufacturing facilities to assist SA fashion designers with their marginal units. Entrepreneur Magazine (2018:6) acknowledged this challenge for SA fashion designers by affirming that since the closures of manufacturing mills during the late 1990s, it had become increasingly difficult to locate reliable manufacturing facilities in SA willing to produce the minimum units SA fashion designers often required.

The challenge with fabric was that the acquisition of fabric consumed the most time, as most fabrics were not readily available in SA to achieve consistent bulk productions required for the retail clothing industry. Recognising the challenge with textile production, Roberts and Thoburn (2004:126) proved that globalisation did indeed exemplify its opportunities and threats through the textile industry, as the subSaharan African textile industry contributed to a significant percentage of employment in the manufacturing sector, so necessary adjustments in the local industry would have a significant effect on income and employment locally. As a result, Business Partners (2014) declared that though the SA textile and clothing industries were small, there were plans in place to assist in the utilisation of all the natural, human and technological resources available nationally to ensure that those resources became soughtafter internationally. Furthermore, government departments such as the DTI reported that there are operations underway to unveil new strategies to protect the local textile industry (Hans, 2019).

Conversely Burke (2013:47) underlined that in order to curb the production challenges, smallbusiness proximity manufacturing required other small manufacturers specialising in a smaller niche market. The exorbitant prices local manufacturers charged SA fashion designers due to the minimal units was found to be one of the challenges experienced when working with local manufacturers. According to Jackson and Shaw (2001:137), manufacturers are compelled to be more competitive than ever, with pricing, design, quality, delivery, and value for money as the current market exhorts pressure. Even so, local manufacturers have not recognised that increasing demand from a growing number of local fashion designers, which could potentially contribute significantly to the manufacturing business.

Concurrently, this study found that closely linked with textile- and clothing-manufacturing challenges were the issues of quality and pricing or costing challenges. Some SA fashion designers found that outsourcing to certain local CMTs compromised their quality, which in turn took away the justification for the premium pricing of their designer ranges. Furthermore, the exorbitant prices CMTs charged SA fashion designers affected the costing of the designer ranges by pushing the product costing higher than anticipated. Kaya (2011:168) likewise found that the challenges that were taken into consideration when outsourcing production to manufacturers or CMTs or textile suppliers included quality management, restrictions on capacity, reduced probabilities of satisfying due dates, disruption risks, discounting schemes, reliability, and flexibility of the selected suppliers.

One other major disadvantage mentioned by Burke (2013:47), and by some participants in this study, was regarding the communication barriers between the fashion designers and the manufacturers when outsourcing, though outsourcing locally enables the fashion designers to contract the manufacturers only when the need arose.

Christopher and Peck (2004:12) found that the limited exchange of information between adjacent entities within the SC-management model created unforeseeable problems that could be avoided through the flow of information, while Seuring and Müller (2008:170) explained that the core essence of a sustainable SC model was the management of material, information and capital flows, together with the collaboration between organisations along the SC.

This limited flow of information thus exposed the major challenge of fragmentation found within the clothing SCM model. Christopher and Peck (2004:1) noted that improved management and control of internal processes and information flow within and between the SC entities would assist with the attainment of the ideals of a fully integrated, efficient and effective SC-management model capable of creating sustainability. Additionally, it was suggested for retailers to take note of backward integration, as it was crucial in accomplishing the required margins, regardless of retail formats (Ayers \& Odegaard, 2017:7). Masteika and Čepinskis (2015:831) suggested that for this "perfect" SC, the SCM model required the inclusion, coordination and collaboration of partners, stakeholders, suppliers, intermediaries, service 
providers and clients to plan and control SCM activities, while Fernie and Sparks (2009:11) implied that retailers should closely collaborate with suppliers in order to ensure effective coordination of activities.

Sirilertsuwan et al. (2018:1346) have revealed that close-proximity clothing manufacturing advances sustainability while benefiting the bottom line. Their findings further showed that the government's role in supporting the improvement of proximity manufacturing involves the following: formation of clothingindustry clusters with different types of suppliers and service providers; the issuing of favourable trade policies; the utilisation of carbon-footprint taxation on imported garments; the offering of tax credit for proximity garments; recycling-programmes support; machinery, technology and business-operations financing support; education support; process-development support; business-collaboration support; technical business-infrastructure support; the sharing of resources with neighbouring governments; the implementation of environmental laws and regulations for water usage, chemical release, gas emission and filtration technology; the offering of clean sources of energy; beneficial labour laws and regulations; stringent health regulations and laws; and the passing of laws and regulations to ensure that the country of origin can be identified in advertising.

\section{Conclusion and Recommendations}

Overall, challenges identified in this paper affected the SCM process of SA fashion designers in its entirety and not just certain parts in isolation. As a result, each challenge was found to have a very close association to most of the other challenges.

The focal recommendations identified to counteract these SCM challenges was communication and flow of information. Several participants were in agreement and acknowledged that the SCM process of SA fashion designers in the retail clothing industry required an efficient communication and effective flow of information between retailers and designers, designers and manufacturers, and all other parts of the value chain.

The major factors that were recommended by participants to drive this effective communication to counteract all these challenges were (i) close-proximity hubs for SA fashion designers, (ii) the establishment of a national fashion council and regional fashion councils, and (iii) the visible presence of mediators and value-chain support from agents and business consultants.

Close-proximity hubs for SA fashion designers were recommended by most participants. Furthermore, the recommendation was for those close-proximity hubs to be easily accessible and available for SA fashion designers, thus, the location of those hubs in major SA cities would be pivotal.

Over and above establishing hubs, participants recognised that the trade-show platforms the DTI supported to provide international retail exposure for SA fashion designers, required further research and consistency. Participants noted that to establish a presence at trade shows, consistent attendance was required for about three to five consecutive years at the same trade shows for fashion designers to be recognised by retailers or distributors. Hence, it is recommended that government departments do some research on relevant trade-show and fashion showcasing platforms, with great potential to offer SA fashion designers to the retail clothing industry international retail opportunities, and to consistently support the same fashion designers at the same relevant platform for a suitable period. Again, the abovementioned could potentially be recognised through a national fashion council that works very closely with government departments.

In addition, one of the significant recommendations to ameliorate the SCM challenges that the fashion designers in SA are facing is that fashion and retail education should be re-evaluated. Some participants expressed the need for specialised knowledge of the SCM process, and this knowledge can only be acquired through education. It is therefore recommended that fashion and retail clothing educational institutions should collaborate and work towards achieving a common standard that would build credibility for the fashion and retail clothing industries.

\section{Limitations}

The analysis of data collected in this research study was limited to the views, feedback and consequent actions of SA fashion designers, SA clothing retailers and supporting institutions at the specified time of the interviews. As a result, there were no quantifiable follow-up interviews to evaluate the proposed solutions to the challenges identified over time as in longitudinal studies. Instead, the 
challenges of the SC model and the proposed solutions were only based on the knowledge of SA fashion designers, clothing retailers and stakeholders, in concurrence with existing SC theories.

The total population size of SA fashion designers in the retail clothing environment was not documented, and the population included only retailers and supporting industries, so there was a limitation with the population group, as SC model partners such as manufacturers or CMTs, fabric suppliers and fashion weeks could not be reached. The SC challenges identified only represented the most valued input from esteemed and experienced fashion designers, retailers, and other industry stakeholders in SA.

\section{Direction for Future Studies}

Studies related to effective communication throughout the SCM process could potentially be carried out. This would outline the best communication approaches and tools to utilise throughout the SCM process. These studies would potentially ensure better communication between SA fashion designers and SC partners of the retail clothing industry.

\section{References}

Anon. 2004. Truworths buys YDE. Mail \& Guardian: May 20. http://mg.co.za/article/2004-01-07-truworths-takesover-yde [13 October 2015].

ATLAS.ti. 2018. ATLAS.ti 8 windows user manual.

http://downloads.atlasti.com/docs/manual/atlasti_v8_manual_en.pdf [15 September 2019].

Ayers, J.B. \& Odegaard, M.A. 2017. Retail supply chain management. CRC Press.

Belotto, M.J. 2018. Data analysis methods for qualitative research: Managing the challenges of coding, interrater reliability, and thematic analysis. The Qualitative Report. 23(11):2622-2633.

Bennet, M.S. 2017. Africa's inspired apparel sourcing hotspot: Lesotho's textiles, apparel \& footwear manufacturing industry. https://www.tralac.org/images/News/Documents/Lesotho\%20textiles,\%20apparel\%20\&\%20footwear\%20m anufacturing\%20industry\%20Synopsis\%20Publication\%20March\%202017.pdf. [30 June 2019].

Burke, S. 2013. Fashion Entrepreneur. Burke Publishing.

Business Partners. 2014. The South African textile and clothing industry - an overview. https://www.businesspartners.co.za/en-za/entrepreneurs-growth-centre/usefularticles/manufacturing/the-south-african-textile-and-clothing-industry-\%E2\%80\%93-an-overview [18 May 2019].

CFDA. 2016. Fashion manufacturing initiative. https://cfda.com/resources/manufacturing-initiative [2 April 2020].

Charmaz, K. 2011. Grounded theory method in social justice research. In: Denzin, N.K. and Lincoln, Y.S. (eds.) The Sage handbook of qualitative research. Sage. 359-385.

Christopher, M. 2000. The agile supply chain, competing in volatile markets. Industrial Marketing Management. 29:3744.

Christopher, M. \& Peck, H. 2004. Building the resilient supply chain. International Journal of Logistics Management. 15(2):1-13.

Christopher, M. \& Towill, D. 2002. Developing market specific supply chain strategies. The International Journal of Logistics Management. 13(1):1-14.

Design Indaba. 2019. Woolworths: Celebrating quality and design for 85 years. https://www.designindaba.com/profiles/woolworths [31 October 2019].

Dinnen, J. 2014. Phase \#2: Clearly define your research strategy. https://www.mackenziecorp.com/phase-2-clearlydefine-research-strategy/ [4 February 2018].

Druesedow, J.L. 2010. "Ready-to-wear." In: V. Steele. (ed.) The Berg Companion to Fashion. Oxford: Bloomsbury Publishing. http://dx.doi.org.libproxy.cput.ac.za/10.5040/9781474264716.0013118 [4 November 2019].

Entrepreneur Magazine, 2018. How to start a clothing business? https://www.entrepreneurmag.co.za/askentrepreneur/start-up-industry-specific-ask-entrepreneur/how-do-i-start-a-clothing-business/6/ [16 May 2019].

Ferdows, K., Lewis, M.A. \& Machuca, J.A. 2005. Zara's secret for fast fashion. Harvard Business Review. 82(11):98-111.

Fernie, J. \& Sparks, L. 2009. Logistics and retail management: Emerging issues and new challenges in the retail supply chain. Kogan page publishers.

Fin24. 2018. SA aims to patch up threadbare clothing industry. https://www.fin24.com/Economy/sa-aims-to-patch-upthreadbare-clothing-industry-20180117-2 [16 May 2019].

Fletcher, K. 2010. Slow fashion: An invitation for systems change. Fashion Practice. 2(2):259-265.

Gail, B. 2018. 25 Advantages and Disadvantages of Qualitative Research. https://brandongaille.com/25-advantagesdisadvantages-qualitative-research/ [10 August 2020] 
Gaimster, J. 2012. The changing landscape of fashion forecasting. International Journal of Fashion Design, Technology and Education. 5(3):169-178.

Giertz-Mårtenson, I. 2010. Fashion forecasting. In: Skov, L. (ed.) Berg encyclopedia of world dress and fashion: West Europe. Oxford. Bloomsbury Fashion Central.

http:/ / dx.doi.org.libproxy.cput.ac.za/10.2752/BEWDF/EDch8029 [03 April 2019].

Hans, B. 2019. DTI to unveil master plan to protect textile industry from cheap imports.

https://www.iol.co.za/news/politics/dti-to-unveil-master-plan-to-protect-textile-industry-from-cheapimports-18924404 [18 May 2019].

Jackson, S. 2009. Meeting the supply chain needs of the fashion retail sector. Supply Chain Europe. 16(3):22-23.

Jackson, T. \& Shaw, D. 2001. Fashion buying and merchandising management. England. Palgrave.

Jensen, E. \& Laurie, C. 2016. Doing real research: A practical guide to social research. Sage.

Jung, S. \& Jin, B. 2016. Sustainable development of slow fashion businesses: Customer value approach. Sustainability. $8(6): 540$.

Kaya, O. 2011. Outsourcing vs. in-house production: a comparison of supply chain contracts with effort dependent demand. Omega. 39(2):168-178.

Kesper, A.P. 1999. June. Small clothing manufacturers in the Johannesburg inner city. Urban Forum. 10(2):137-164.

Kimani, N. 2016. The importance of a fashion council. https://tdsblog.com/the-importance-of-a-fashion-council/ [2 April 2020].

Kumar, R. 2014. Research methodology: A step-by-step guide for beginners. Sage.

Legard, R., Keegan, J. \& Ward, K. 2003. In-depth interviews. In: Ritchie, J., Lewis, J., Nicholls, C.M. and Ormston, R. (eds.) 2013. Qualitative research practice: A guide for social science students and researchers. London. Sage.

Madikwa, Z. 2011. Blow for Stoned Cherrie. http://www.sowetanlive.co.za/goodlife/2011/07/21/blow-for-stonedcherrie. [13 October 2015].

Masteika, I. \& Čepinskis, J. 2015. Dynamic capabilities in supply chain management. Procedia-Social and Behavioural Sciences. 213:830-835.

Moorad, Z. 2015. Aca Joe owner placed under liquidation.

http://www.bdlive.co.za/business/retail/2015/07/31/aca-joe-owner-placed-under-liquidation. [13 October 2015].

Neuman, L.W. 2011. Social research methods: Qualitative and quantitative approaches. 7th Edition. England. Pearson Education Limited.

Ngubane, S. 2011. The Business of South African Fashion.

http:/ / www.ifashion.co.za/index.php?option=com_contentandview=articleandid=3314andcatid=78andItemid=114. [19 October 2017].

Nyhaba, T. 2009. Sun Goddess Shrinks to One Remaining Store.

http://www.ifashion.co.za/index.php?option=com_contentandtask=viewandid=1621. [13 October 2017].

Palmi, R. 2007. Inside-out: South African fashion designers' sewing success. Unpublished Doctoral thesis. KwaZulu-Natal. University of KwaZulu-Natal.

Pitman, J. 2009. Jenni Button. http://www.entrepreneurmag.co.za/advice/success-stories/entrepreneurprofiles/jenni-button/. [13 October 2017].

Ramdass, K. 2011. Alignment Strategies for the Clothing Industry in SA: Lessons Learned. http:/ / uir.unisa.ac.za/bitstream/handle/10500/19865/13R0476.pdf?sequence=1 [11 August 2016].

Roberts, S. \& Thoburn, J.T. 2004. Globalization and the South African textiles industry: Impacts on firms and workers. Journal of International Development 16(1):125-139.

Saunders, M.N., Lewis, P. \& Thornhill, A. 2015. Research methods for business students. 7 th ed. India. Pearson Education.

Shields, P.M. 1998. Pragmatism as a philosophy of science: A tool for public administration. https://digital.library.txstate.edu/bitstream/handle/10877/3954/fulltext.pdf [22 September 2017].

Shukla, R.K. 2016. Coordination practices in supply chain management. Journal of Management Research. 16(1).

Sirilertsuwan, P., Ekwall, D. \& Hjelmgren, D. 2018. Proximity manufacturing for enhancing clothing supply chain sustainability. The International Journal of Logistics Management. 29(4):1346-1378.

Snape, D. \& Spencer, L. 2003. The foundation of qualitative research. In: Ritchie, J., Lewis, J., Nicholls, C.M. and Ormston, R. (eds.) 2013. Qualitative research practice: A guide for social science students and researchers. Sage.

Seuring, S. \& Müller, M. 2008. Core issues in sustainable supply chain management - a Delphi study. Business Strategy and the Environment. 17(8):455-466.

Textile Federation. 2007. Current trading environment. http://www.texfed.co.za/. [18 May 2019].

Tilly, C., Agarwala, R., Mosoetsa, S., Ngai, P., Salas, C. \& Sheikh, H. 2013. Informal worker organizing as a strategy for improving subcontracted work in the textile and apparel industries of Brazil, South Africa, India, and China. https:/ / escholarship.org/content/qt4f48040t/qt4f48040t.pdf [10 November 2019].

Tobler-Rohr, M.I. 2011. Handbook of sustainable textile production. Elsevier. 
Traub-Merz, R. \& Jauch, H. 2006. The African textile and clothing industry: from import substitution to export orientation. In: Jauch, H. and Traub-Merz, R. (eds). Future of the Textile and Clothing Industry in Sub-Saharan Africa. Bonn. Friedrich-Ebert-Stiftung.

Truworths. 2015. Integrated Report 2015. [https://www.truworths.co.za/annualreport2015/fashion-andbrands/group-brands.html [26 August 2016].

Woolworths. 2009. Woolworths extends its SA designer's range.

http://www.ifashion.co.za/index.php?option=com_content\&task=view\&id=2065 [11 April 2020]. 